\title{
Poética do sujeito: sobre a "Ética das verdades" nos contos de Miguel Torga
}

Ermelinda Maria Araíjo Ferreirci Universidade Federal de Pernambuco

Para Cleonice Berardinelli

Toda invocaçio do solo, do sangue, da raça, do costume e da comunidade trabalha diretamente contra as verdades, e é precisamente esse conjunto o que se clesigna como inimigo da "ética das verdades".

Alain Badiou
Escrevi n'A Ciraçāo do Mumdo que a minha Pátria civica acaba em Barca D'Alta e a minha Pátria telúrica acaba nos Pirenetis. Radicalmente, do ponto de vista civico, temos uma fronteira e a nossa realidade social e coletiva acaba ali. Mas, quando nos despimos de conceitos sociológicos e entramos no mundo do Homem mdical, al fronteira è talo absurda como seria para um bicho se este tivesse consciência. Para estes nito hi fronteiras. Perceberam?...

Miguel Torga

\section{1 . Introdução}

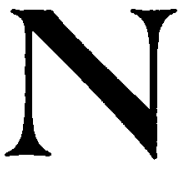

a base da pequena escultura de Rodin intitulada le stuis belle encontra-se, escrito à mào na superfície de bronze em letras irregulares e quase imperceptiveis, o seguinte trecho do poema de Baudelaire "La beauté":

- Doutora em Letras pela PUC-Rio e autora dos livros Cabeças Compostas: A Personagem Feminina na Narratita de Osman Linse A Mensagem e a Imagem: Literatura e Pintura no primeiro modernismo portıgıês. 
Je suis belle, ô mortels! comme un rêve de pierre, Et mon sein où chacun s'est meurtri tour à tour, Est fait pour inspirer au poète un amour Éternel et muet ainsi que la matière.

A escultura representa um homem musculoso que ergue para o alto, com seus poderosos braços, o corpo frágil e encolhido de uma mulher. Nua, com os joelhos apertados de encontro ao peito, toda ela apóia-se no tórax do homem, numa posição quase impossivel. Curvado para trás num esforço supremo, o homem consegue elevar a pequena figura feminina, que mais parece um bloco de pedra, acima da sua própria cabeça. Com a coluna inclinada e o braço erguido com entusiasmo, o homem, num relance, já não é apenas um homem: é um gesto de vitória.

Rodin ergue à matéria um elogio em forma humana. A força do espírito criador, representada no corpo-coluna, ergue o bloco de pedra para o alto, e ele já parece suave, frágil e flexível, mas resistente e elástico como um corpo feminino. Pode-se ler essa escultura em muitos sentidos: como uma reflexão sobre a experiência de elevação e de transcendência presente na criação humana em geral; como uma auto-reflexão sobre a arte de esculpir, em particular - que implica em dominar, moldar, tornar visível na pedra bruta e informe a ação humana e seu significado; ou ainda como uma ampla analogia à Criação. Na primeira, a matéria pode ser som, cor, palavra. Na segunda é barro, pedra, bronze, mármore. $\mathrm{Na}$ terceira, é água, fogo, ar... terra.

"Je suis belle" - é o título nem um pouco modesto da obra. Belos são os corpos representados, bela é a escultura como um todo, bela é a matéria de que é feita. Bela e mutável é toda a matéria de que são feitas todas as formas que o tempo desfaz. A sua eternidade advém desse movimento: ela é movimento. Se hoje os modelos vivos de Rodin já não existem como formas, amanhã será a própria escultura que desaparecerá, revelando-se em sua realidade de sonho: "un rêve de pierre". Pois, por mais intensas que sejam as forças estruturadoras da matéria, como a densidade, a resistência e a coesão, nenhuma é capaz de vencer para sempre o poder desagregador do tempo. Tudo o que é está condenado a não-ser, 
e em tudo o que ainda não é parece esconder-se uma possibilidade, uma suspeita, um impulso, um desejo, talvez, de forma.

No poema, o ser da escultura - que nos faz pensar também no ser vivo, igualmente lapidado num corpo onde experimenta a alegria e a dor - denuncia a sua finalidade: inspirar no poeta um amor eterno e mudo como a matéria. Esse poeta pode ser o que assim se reconhece, aquele que busca inspiração na natureza para realizar a obra de arte; ou o aspirante à poesia, que observa a obra de arte para compreender a sua natureza. Mas também pode ser aquele que nenhuma relação tem com a arte exceto a cle ser, ele mesmo, de uma certa maneira, a própria obra: o poeta banal, o homem comum, o bicho instintivo, cuja realização "limita-se" ao ato de existir e de testemunhar na própria carne o drama silencioso, lento e cruel da natureza da qual faz parte. Nesse caso, é a matéria que parece se comprazer em experimentar a resistência do ser nela aprisionado, testando-o em sua força de vontade nos momentos mais simples, porém mais extremos, do estranho processo da vida - o nascimento, a procriação, a doença, a morte. Através da matéria, a vida parece sondar a capacidade do ser de amar e de suportar a consciência de sua própria finitude.

Poeta em todos os sentidos, Miguel Torga está tão próximo do amor "eternel et muet comme la matière" quanto o homem retratado por Rodin em sua escultura: ambos erguem a matéria acima de suas próprias cabeças, ou de sua razão e de seu intelecto; e o bloco de pedra que se feminiza nas mãos de Rodin e de seu personagem é como o rincão de terra, a montanha, a serra que se feminizam nas mãos de Torga, no corpo de suas personagens. $O$ apego de Torgal à terra aproxima sua arte da escultura. Nāo pelo material que emprega - a palavra - que pressupõe ruido, transitoriedade, incompreensĩo; mas pelo gesto suave, de amante atento, que usa para tocá-la; pelo silêncio com que a envolve em seus textos; pelo universo rude onde se refugia com ela, em seu discurso quieto e profundo.

Em Torga, a palavra - "violência faminta de ternura" - quase não diz. É como se estivesse submissa a uma sabedoria bruta e não lapidada, maior e mais verdadeira que qualquer tentativa de raciona- 
lização. Nos textos simples e limpos de Torga a palavra cede lugar, muitas vezes, a uma intuição silenciosa, que comunica intensamente, e o que comunica é o amor, a liberdade, a verdade: "aquela tríacle bendita" - como diz ele na última frase de seu último diário - "que justifica a passagem de qualquer homem por este mundo".

Poderíamos comentar aqui sobre os belos ensaios de amor e de liberdade que ele executa ao longo de suas narrativas - Bichos, Contos da Montanbae Novas Contos da Montanba-; mas escolhemos falar da verdade, por ser um tema que engloba os demais, e porque parece apontar insistentemente para um aspecto muito peculiar da obra de Torga: a questão da ética como uma poética do stujeito.

Em seu ensaio "Representações da Justiça", apresentado no Colóquio Internacional Miguel Torga, realizado no Porto, em 1993, - jurista J. N. Cunha Rodrigues menciona a importância desta questão para a compreensão da unidade da obra de Torga. Segundo o jurista, há uma característica comum que atravessa todos os textos do escritor "como um rio subterrâneo que dá harmonia aos gestos superficiais" e que o poema intitulado "Lei" exprimiria como enunciado de uma ordem a que poderíamos chamar lei da terra:

Pode-se dizer que esta "lei" corre sobre um rio de águas mansas; relativamente à liberdacle, a imagem mais adequada serí a de uma corrente torrencial que se despenha em cada frase e em cada verso e que arrasta, destrói ou remove o que se lhe opõe. Torga é o cidaclão e o poeta da liberdade. $A$ liberdade em Torga é natural e instintiva. É um poder teluricamente mediado, no sentido de que enraizado no bomem como ser intrinsecamente envolvido no cosmos. Se nos quisermos aproximar da tópica jurídica, é um atributo da pessoa como ser único e irrepetivel. Ou, na definição do poeta, uma condiçăo do indivíduo antes de ser um destino social.'

A lei da terra que vigora em seus textos parece-nos menos uma forma de falar de uma geografia física e humana do que a tentativa de entrar na composição e no devir de algumas verdades eternas. Diz Alain Badiou que a "ideologia ética" é, em nossas

' RODRIGUES, 1993. p. 10. 
sociedades, o principal adversário de todos aqueles que se esforçam por dar lugar a um pensamento, seja ele qual for. Por isso, partindo de uma crítica radical da "ideologia ética" e de suas variantes socializadas, ele opõe uma "ética das verdades", que não se propōe nem a submeter o mundo alo reinado absträto de um Direito, nem a lutar contra um Mal exterior e radical. Ela tenta, ao contrário, por sua fidelidade própria às verdades, deter o Mal - que reconlieceu como o inverso, ou a face obscura dessas verdades.

Como di\% Torga em seu Diário IV: "A verclade nua e crua cxige extremos: só em inteira purezal ou em inteira devassidão. Porque a devassidão encaminha para a lucidez, que é a primeira condiçio dă verdacle". 2 É difícil encontrar com precisão um sentido patriótico, regionalista ou icleológico para a "terra" nos textos cle Torga. A "terı", parà ele, não é um lugar, c não é cle forma alguma um sinônimo de estabilidade e de imobilidade, como tem-se algumas vezes interpretado. $A$ terra está, simbolicamente, no espírito humano que se aferra a que nele existe de mais autêntico, de mais genuíno. De certa forma, a "terra" é, para Torga, um sinônimo de "verclade". E a inocência da clevassa Mariana, que a virgem Marilia, com a sua visĩo preconcebida clo Mal, inculcado como uma moraliclade vazial de experiência, não pode compreender.

Símbolo da "terra humilde", Mariana é, no entanto, uma figura nômacle, em contínuo movimento de deslocamento e de busca. Por isso

compreende tudo, menos o afeiçoamento da perdiz ao monte nativo. Todos os horizontes lhe acenam da mesma maneira. $A$ terra parece-lhe una, indivisivel, nivelada na mesma serenidade ce no mesmo clestino de criar.'

Em Mariana, portanto, Torga esculpe com grande clareza uma imagem cle sua "lei da terra", de sua ética "telúrica", ou, na terminologia de Alain Badiou, de sua "éticá clas verdacles".

: TORGA, 1986. p. 137.

'TORGA, 1990. p. 115. 


\section{A "Ética das Verdades", segundo Alain Badiou}

Apenas declarando querer aquilo que o conservadorismo decreta ser impossível e afirmando as verdades contra o desejo do nada é que nos afastamos do niilismo.A possibilidade do impossivel, que todo encontro amoroso, toda reformulação científica, toda invenção artística e todo passo da política da emancipação pỏem sob nossos olhos, é o único principio - contra uma ética do bem-viver, cujo conteúdo real é decidir a morte - de uma ética das verdades.

Alain Badiou

Não podemos muclar a hora da chegada,/Nem talvez a mais certa,/ A da partida./Mas podemos fazer a descoberta/ Do que presta/ E não presta/Nesta vida./E o que não presta é isto, esta mentira/ Quotidiana,/ Esta comédia desumana/ E triste,/ Que cobre de soturna maldição/ A própria indignação/ Que lhe resiste.

Miguel Torga

A ética está na moda, lembra Alain Badiou nas primeiras linhas de seu livro Ética: um ensaio sobre a consciência do Mal. E não sem razão. Em toda parte nota-se uma pressão, às vezes sutil, às vezes declarada e exigente, em favor da ética, considerada como um valor em si e até como o maior deles: é a "ética na política", o "movimento pela ética", os "códigos de ética".

Isso vem coincidir com um avassalador recrudescimento do cliscurso dos direitos humanos. Fundamento da "ética dos direitos humanos", esse discurso é, porém, denunciado por Badiou como um niilismo negador de todo pensamento; exceto, talvez, do pensamento mais rigido e conservador. Nega o pensamento porque abarca categorias abstratamente (e comodamente) universais; $\mathrm{e}$ anima o conservadorismo porque amortece assim a crítica dos processos singulares.

Efetivamente, a idéia de direitos humanos pressupōe, de um lado, um Homem em geral - isto é, um arquétipo, um construto imaginário, produzido na e pela Revolução de 1792; e de outro lado, um Mal também universal, absoluto e primordial, cujo estofo vem 
mais da Religião clo que da Filosofia. O Mal é aquilo a partir do que se dispõe um Bem, e não o contrário. Os "direitos humanos" são, portanto, os direitos ao não-Mal: não ser ofendido ou maltratado em sua vida, em seu corpo e em sua identidade cultural. A ética é aqui concebida ao mesmo tempo como capacidade de apriori distinguir o Mal (porque, segundo o uso moderno da ética, o $\mathrm{Mal}$ - ou o negativo - vem primeiro: supôe-se um consenso sobre o que é errado), e como princípio último do julgamento político: a ética é justamente o que intervém de maneira visível contra um $\mathrm{Mal}$ identificável a priori.

$\mathrm{Na}$ contracorrente do consenso e fiel às suas raízes, Badiou nos recorda de como nos anos 60 e 70 o anti-humanismo militante de Foucault, Althusser e Lacan já havia declarado a "morte do Homem", esse mesmo Homem - com maiúscula - que agora ressuscita por toda a parte. E essa recusa da noção de homem universal, ao contrário de estabelecer padrões conservadores e/ou narcísicos, produz, agora como então, um inconformismo ativo, produtivo, expresso em palavras e em atos. É em torno desse inconformismo que o filósofo propôe uma outra concepção de ética, mais precisamente uma "ética das verdades", referida a situações concretas e voltada contra essa vaga "ética dos princípios", hábil em denunciar por toda a parte um Mal radical.

Badiou reconhece, no entanto, que a força da ética dos direitos humanos resicle, em primeira instância, na sua eviclência. Com efeito, sabe-se pela experiência que o sofrimento é visivel. Já os teóricos do século XVIII haviam feito da piedade - identificação com o sofrimento do ser vivo - a mola-mestra da relação com outrem. Que a corrupção, a indiferença ou a crueldade dos dirigentes políticos são as causas maiores de seu descrédito, os teóricos gregos da tirania já o notavam. Que é mais fácil constituir um consenso sobre o errado do que sobre o certo, as igrejas já tiveram essa experiência: sempre thes foi mais fácil indicar o que não deve ser feito - ou seja, contentar-se com as abstinências - do que definir o que deve ser feito. 
Poder-se-ia dizer, entảo: eis um corpo de evidências capaz de cimentar um consenso planetário e adquirir a força de sua imposiçio. E no entanto é preciso sustentar que não é isso, que essa ética é inconsistente e que a realidade, perfeitamente visivel, é o desencadeamento dos egoísmos, a desaparição ou a extrema precarieclade das políticas de emancipação, a multiplicaçào das violências "étnicas" e a universalidade da concorrência selvagem."

Badiou vê, pois, na corrente de opinião que a todo instante evoca a "ética", um grave sintoma de renúncia daquilo de único que distingue a espécie humana do ser vivo predador que ela também é: "a capacidade de entrar na composiçāo e no devir de algumas verdacles eternas". Mas o que seriam essas "verdades"?

Consideremos alguns conceitos fundamentais de sua teoria: acontecimento, verdade, sujeito, consistência. Para o filósofo, se não há uma ética "em geral" é porque falta o sujeito abstrato, aquele que deveriá possuí-la. Não hả senão um animal particular, convocado pelas circunstâncias a se tornar sujeito. Isto quer dizer que tudo o que ele é, seu corpo, suas capacidades, em certo momento é requisitado para que uma verdade faça o seu caminho. Então o animal humano é intimado a ser o "imortal" que não era.

Digamos que um sujeito, que ultrapassa o animal (mas para o qual o animal é o único suporte), exige que haja ocorrido alguma coisa de irredutível à sua inscrição ordinária no "aquilo-que-há", ou seja, na sua situação habitual e corriqueira. Esse suplemento é o que Badiou denomina de acontecimento: algo que, estando fora de todas as leis regulares da situação, nos obriga a inventar e a decidir uma nova maneira de ser e de agir dentro da situação.

A decisão do sujeito de se referir à situação, daí por diante, do ponto de vista do acontecimento, origina então o que Badiou entende por processo de uma verdade: "A fidelidade ao acontecimento é ruptura real (pensada e praticada) na ordem própria em que o acontecimento teve lugar (político, amoroso, artístico, científico). Chamamos "verdade" ( $u$ ma verdade) ao processo real de uma

+ BADIOU, 1995. p. 24. 
fidelidade a um acontecimento. Aquilo que essa fidelidade prodız na situaç̧io"."

Diferentemente do ser humano biológico, Badiou chama de sijeito ao suporte de uma fidelidade, ao suporte de um processo de verdade. O sujeito não preexiste ao processo. É absolutamente inexistente na situaçào "antes" do acontecimento. Pode-se dizer que o processo de verdade induz um sujeilo. E é com relação a tais sujeitos que talvez seja legítimo falar de uma "ética das verdades".

Para Badiou, o stijeito, preso assim como ponto-suporte alo processo de uma verdade, é simultaneamente ele-mesmo, uma singularidade múltipla reconhecivel entre todas; e em excesso sobre ele-mesmo, porque o traçado aleatório da fidelidade passa por ele, transita por seu corpo singular e o inscreve, do próprio interior do tempo, num instante de eternidade.

A ética de uma verdade é expressa pelo conflito crônico entre cluas forças que agem no sujeito: de um lado, o pertencer a uma situaçào, aquilo que se pode chamar o principio de interesse do ser, seu instinto de conservação. De outro lado, o pertencer à composiğio de um stijeito de verdade, que depende de um traţado próprio, de uma ruptura continuada, do enlace do que é conhecido pelo que ainda não é, ou aquilo que se pode chamar de princípio subjetivo.

É nesse ponto que Badiou enuncia a ética de uma verdacle como aquela que afirma ao stieito: "Faz tudo o que puderes para fazer perseverar o que excedeu tua perseverança. Persevera na interrupçào. Captura em teu ser aquilo que te capturou e te deteve"."

É no cerne paradoxal dessa máxima - "Continuar!" - que nós encontramos, assim dependente do Bem (as verdades), a verdadeira figura do Mal, em suas três espécies: o simulacro ("ser o fiel aterrorizante de um falso acontecimento"), a traiçio (ceder em uma verdade em nome de interesses próprios), e o desastre (crer que a potência de uma verdade é total e partir para a sua generalização,

\footnotetext{
'BADIOU, 1995. p. 55.

"BADIOU, 1995. p. 60.
} 
para a sua imposição aos outros). O Mal, segundo essa percepção, é uma possibilidade só aberta pelo encontro do Bem. A ética das verdades, que vai apenas dar consistência a esse sujeito que somos e a quem aconteceu ter de sustentar com sua própria perseverança animal a perseverança intemporal de um sujeito de verdade, é também o que tenta deter o Mal por sua inclusão efetiva e tenaz no processo de uma verdade. A ética das verdades combina então, sob o imperativo de "Continuar!", um recurso de discernimento (não se prender aos simulacros), de coragem (não ceder), e de reserva (não se dirigir aos extremos da Totalidade).

\section{Miguel Torga: Humanismo ou "Ética das Verdades"?}

A salvaçåo não está numa regra de manual; é uma conquista que se faz, pisando muitas vezes no caminho a presença melancólica da virtude. Miguel Torga, Diário I, p. 41.

O tão decantado bumanismo de Miguel Torga não é tão evidente nem tão indiscutível como parece. Não é, sobretudo, uma expressão do humanismo filosófico - não segue nenhuma escola; nem da moralidade religiosa - não se prende a dogmas nem professa a defesa de nenhuma crença. A lei vigente em seus contos também não obedece aos princípios do Direito como um sistema de controle social, nem se curva à nenhuma regra institucional ou código de consenso comunitário.

O amoralismo 7 talvez seja a única dominante em sua escritura; e, no entanto, jamais invade o terreno do imoral, da perversão, da

\footnotetext{
'Designa-se como amoralismo a doutrina ou atitude que nega a possibilidade de formulação de juízos morais, por não admitir que possam ter o fundamento objetivo universal necessário ao caráter normativo categórico (relativo ou absoluto) que essencialmente os qualifica. (Cf. JAPIASSU, Hilton. Dicionário Básico de Filosofia).
} 
transgressão, enfim, de um Mal previamente definido em relação ao qual haveria um Bem desejâvel que lhe seria contrário. Surpreedentemente, Torga nos coloca diante de impulsos individuais instintivos, pouco ou nunca premeditados, aos quais seus personagens se aferram com tamanha fidelidade que é impossível não interpretálos como um Bem primordial, ou pelo menos, natural. Por isso, a impressão mais forte que os seus textos veiculam é a de uma sinceridade pura e incondicional, que não só denuncia a artificialidade das leis e convençōes do grupo, como também nos surpreende e encanta com o impacto profundo e simples da verdade que revela.

Ainda que os grupamentos humanos, identificados e nomeados em seus contos geralmente em bloco, manifestem por vezes a tendência de interpretar os fatos conforme uma codificação apriorística, o que prepondera quase sempre é o ponto de vista do sujeito, no sentido proposto por Badiou - ou seja, daquele animal humano e previsível que se depara diretamente com a experiência e o desafio do acontecimento, e vê-se forçado por ele a agir de uma maneira nova e diferente à da coletividade; a ser de acordo com a exigência do suplemento de vida que o acomete e excede a sua situação habitual.

Não importa a natureza do acontecimento: seja banal e cotidiano, seja extremo e violento, é nele que o siljeito se revela. Doenças, assassinatos, suicídios, traiçōes, vinganças; e paixões, nascimentos, descobertas concorrem indiferentemente para a deflagração do processo de uma verdade. Tudo está ali e nada pode ser condenável, ainda quando parece que deveria ser. Mas a autenticidade dos sitjeitos, indelevelmente comprometidos com os processos de verdade que os atingem, é tão intensa que os ultrapassa enquanto individuos, atravessando-os para se projetar no mundo circundante enquanto verdade, não humanística, não humanitária: apenas bumana.

Estariamos diante de um bumanismo? Ora, o humanismo parte do princípio de um Homem universal, o homem como idéia de identidade natural ou espiritual, que é o fundamento da doutrina ética no sentido em que é entendida hoje: legislação consensual 
referente aos homens em geral, suas necessidades, sua vida e sua morte. Ou ainda: delimitação evidente do que é o Mal, do que não se coaduna com a essência humana.

Parece-nos que nem uma coisa nem outra se evidenciam na obra de Torga. Nem a idéia de uma identidade espiritual naturalmente bumana, pois à comunidade uniforme que constitui o ponto de partida de suas narrativas opõe-se quase sempre o sujeito de uma verdade - uma vontade - que se destaca do todo; nem tampouco a delimitação evidente do que é o Mal, sempre redimensionado e relativizado em seus contos.

Devido à sua estrutura e temática, contudo, os textos de 'lorga já foram acusados de um esquematismo calcificado; e a pouca inovação formal de seus contos já foi interpretada como uma tendência à realização de meras "estórias de proveito e exemplo", inseridas de maneira estanque no contexto da "literatura engajada" dos primórdios do Neo-realismo em Portugal." Pessoalmente, acreditamos que Torga vai muito além desta proposta, e é isso o que tentaremos verificar sondando os caminhos da ética por ele traçaclos em sua obra.

Sabemos que a ética refere-se, em grego, à busca de uma boa "mancira de ser", ou à sabedoria da ação. É uma parte da filosofia que coordena a existência prática com a representação do Bem. Foram os estóicos que com mais constância fizeram da ética o cerne da sabedoria filosófica. "O sábio é aquele que, sabendo discriminar entre as coisas que dependem dele e as que não dependem, organiza sua vontade ao redor das primeiras e suporta impassivel-

\footnotetext{
" "Em Torgal o esquematismo se disfarça na roupagem da ficçào da "excelência natural" da vida primitiva, em termos da osmose homen/naturcza, colocação que resume as histórias de proveito e exemplo, que é o que na verdade temos. O "bom selvagem”, que fez sonhar Rousseau, postulava a volta ao seio maternal da natureza como solução para os conflitos. Com Torga, percebenos que nem a volta é proposta. O que há é uma permanência cos movimentos desta permanência, longe de uma compreensilo de que a ruptura com o horizonte imediato é o que caracteriza a existência do homem." SILVEIRA C AREAS, 1972. p. 61.
} 
mente as segundas". 9 Para os modernos, a ética é quase um sinônimo de moralidade, ou, como diria Kant, de razào prática, em oposição à razão teórica. Trata-se das relações da ação subjetiva e de suas intenções representáveis com uma Lei universal. A ética é o princípio de julgamento das práticas de um sujeito, seja ele individual ou coletivo.

Em seu ensaio "O Desespero Humanista de Miguel Torga e o das Novas Gerações", Eduardo Lourenço interroga-se: "Ao desespero da poesia de Miguel Torga designamos no título destas considerações como "humanista". Porque não simplesmente 'humano'?"... E responde: "Porque este desespero se dá a si mesmo um tempo de reflexão, e desesperando cle tudo respeita os muros da cidade invisível cujo nome é Literatura". ${ }^{10}$

Com isso, Lourenço nos faz supor que Torga veria na Literatura um reduto possível para o exercício de uma visão programática - ou "ética" - da realidade, quando todas as clemais instituiçōes sociais se fizessem desacreditadas. A Literatura preservaria seu poder edificante, transformador e redentor do humano, o que faria de Torga, enquanto agente desse "projeto", um "humanista" literário. Tomamos a liberdade de pôr em questão essa idéia. O próprio Lourenço acaba expondo sua duivida sobre a idéia de um Torga "humanista", no confronto com seus textos que resistem al essa classificação. Daí a necessidade constante de se justificar a respeito da natureza do "desespero" de Torga:

Designamo-lo de bumanista por ser um desespero que voluntária ou involuntariamente reconhece os seus limites, dando-se como forma uma estrutura lingüistica e vocabular com um lugar definido no nosso mundo literário e, como conteúdo, uma vontade de esperar apesar de tudo. Há talvez uma contradição nisso. É difícil dizer se na poesia de Torga a Esperança é mais irredutivel que o Desespero. Depende dos poemas. Certamente o poeta também nào o sabe. [...] De certo modo uma decisão cabe também ao leitor."

\footnotetext{
9 BADIOU, 1995. p. 21.

${ }^{10}$ LOURENÇO, 1955. p.89.

"LOURENÇO, 1955. p.105.
} 
Tranferir para o leitor a responsabilidade de um julgamento já desautoriza por si só a pressuposição da existência um projeto literário humanista na obra de Torga, seja em prosa ou em poesia. Não nos parece, realmente, que seus textos tenham algo de programático, e se professam alguma verdade é talvez uma verdade de caráter apenas humano, o que a torna curiosamente muito mais particular e circunstancial do que esperançosamente universal. A verdade em seus textos é uma mera constataçào, e nunca sucumbe à tentação de se convencionalizar ou de se generalizar, como aconteceria se Torga fizesse alguma concessão à esperança humanista ou humanitária. Tal concessão iria inclusive de encontro a liberdade, valor a que Torga se apega acima de tudo.

De onde se conclui que o bumano, para Torga, é algo muito mais imprevisivel e único do se poderia supor. O bumano sequer é claramente um atributo dos seres instalados em corpos humanos; freqüentemente se revela em outras formas, na geografia dos montes, por exemplo, na voz do vento, na tepidez da terra, no sussurro das árvores, imiscuindo-se sobretudo nos corpos de animais - daí todo um livro dedicado à profunda bumanidade dos bichos. $O$ inverso também acontece: há homens brutos, homens tronco, homens pedra; homens, enfim, sem nenhuma bumanidade. Em seus contos, Torga toca no âmago da questão ética: duvida da existência de um sujeito bumano universal, capaz de coordenar a ética com os direitos do homem e com as ações humanitárias. Seus muitos contos sobre a Justiça e a Lei dos homens são exemplos disso.

Retomando Badiou, vimos que a ética humanista subordina a identificaçào do sujeito ao reconhecimento universal do Mal que lhe é feito. A ética, portanto, define o homem como uma vítima, ou como aquele que é capaz de reconhecer a si mesmo como vítima. Badiou considera essa definição inaceitável. Torga, acreditamos, também. Vejamos porquê.

Para Badiou, essa definição é inaceitável porque o estado de vítima, de besta sofredora, de moribundo descarnado assemelha o homem à sua subestrutura biológica, à sua pura e simples identidade 
de ser vivo, à vida como um mero "conjunto das funções que resistem à morte":

Claro, a humanidade é uma espécie animal, mortal e predadora. Mas nem um nem outro desses papéis pode singulariza-la no mundo dos seres vivos. Como algoz, o homem é uma abjeção animal, mas é preciso ter a coragem de dizer que como rnítima ele geralmente não é melhor. Todos os relatos de torturados e de fugitivos indica isso claramente: se os algozes e os burocratas dos círceres podem tratar suas vítimas como animais destinados ao abatedouro com os quais eles, os criminosos bem nutridos, nada têm $\mathrm{cm}$ comum, é porque as vítimas simplesmente tornaram-se tais animais. Fez-se o que era necessário para isso. ${ }^{12}$

E continua:

Que algumas delas, entretanto, ainda sejam homens e dêem testemunho disso é um fato comprovado. Mas, precisamente, isto é sempre por um esforço inaudito, saudado por suas testemunhas - que ele desperta para um reconhecimento raclioso - como uma resistência quase incompreensivel, neles, daquilo que nào coincide com a identidade da vítima. Ali está o Homem, se fazemos questão de pensá-lo: no que faz que se trate de um animal com resistência diferente da dos cavalos, não por seu corpo frágil, mas por sua obstinaçào em continuar sendo o que é, ou seja, precisamente outra coisa que nào uma vítima, outra coisa que nào um ser-para-amorte, c portanto: outra coisa que nâo um mortal.'s

Quanto a Torga, surpreende que narrativas de cunho tão realista quanto a dos Contos da Montanba a dos Novos Contos da Montanba, que tomam como temática a vida agreste, dificil, apoucada dos aldeões das scrras portuguesas, sujeitos às intempéries, às dificuldades de toda a sorte, à falta de alimento, de saúde, de estudo, de informação, de oportunidades, seja uma literatura tão escassa de vítimas. Ao contrírio do que ocorre com outras narrativas do gênero, que tratam de seres humanos em condições miseráveis, não há

22 BADIOU, 1995. p.25.

"BADIOU, 1995. p.26. 
piedade nem pieguismos nos contos de Torga. Não há sequer o convencional maniqueísmo que divide a realidade entre os "poderosos opressores" e os "pobres oprimidos".

Seus personagens tendem a ser, em geral e sem distinção, impiedosos - não num sentido cruel, mas natural. E isto thes confere uma grande e insuspeitada dignidade. Alheios às leis do mundo para além dos limites da "aldeia", ignorantes de anseios e desejos escravizantes, os miseráveis de Torga são de uma impressionante grandeza, de uma absoluta autenticidade: seja a galeria de doentes que povoa sua obra; sejam os muitos mendigos, assassinos, acusados, os trabalhadores sacrificados, agricultores, pastores e almocreves que ali se encontram, todos parecem focalizados e iluminados em momentos onde se lhes aflora uma verdade qualquer, uma humanidade crua, clara, excessiva, despojada de definições.

Torga não parece fazer de seus textos instrumentos explícitos de reivindicação social e política, desvendando mazelas, denunciando vazios e reduzindo seus atores ao nada feito do "tudo" de que são privados. Seus contos, ao contrário, parecem mais preocupados em revelar a profundidade que existe num ser humano, tudo o que ele é mesmo quando nada "tem", quando nada "sabe". É à essência do humano que Torga se dirige. Essa essência sobrevive e se mantém pela força da própria vida, independente do que lhe sobra ou do que lhe falta. A beleza selvagem de seus personagens resulta dessa consciência, desse respeito imenso do autor pela vida que pulsa num ser, sob quaisquer circunstâncias; pela promessa de imortalidade que cada vida sugere, seja no instante do encontro amoroso, do nascimento ou da morte, de um encantamento, de uma reação violenta, de uma inspiração inesperada, enfim, de um gesto genuino, que torna verdadeira a criatura que a ele se apega com fidelidade.

Curiosamente, a melhor representação do Homem que, no sentido que vimos discutindo, encontramos no primeiro livro de contos de Torga - Bichos, a sua "Arca" - não está figurada num corpo humano, mas no de uma ave, um corvo: Vicente. Sua história 
funciona como um verdacleiro contraponto às histórias dos outros animais deste livro, e como o princípio norteador do comportamento que se esperará dos homens em seus livros subseqüentes.

A ênfase desta obra nos bichos também parece contribuir para o projeto de ressaltar, pela humanidade insistentemente atribuída a eles, um caráter comum a todos: a marca da vítima: Nero, o cão, vítima do orgulho; Mago, o gato, vítima da gula e da preguiça; Morgado, o jerico, vítima da subserviência; Bambo, o sapo, vítima da contemplação; Tenório, o galo, vítima da vaidade; Cega-Rega, a cigarra, vítima do excesso; Ladino, o pardal, vítima da esperteza; Farrusco, o melro, vítima da ironia; Miúra, o touro, vítima da raiva e do medo. A marca da vítima também aparece nos poucos humanos desta obra: Madalena, a mulher, vítima da concupiscência e da vergonha; Jesus, o menino, vítima da curiosidade e da ambição; Ramiro, o pastor, vítima da solidão e O Senhor Nicolau, o cientista, vítima do conhecimento. Todos, enfim, incapazes de um gesto de liberdade, de autonomia; todos esgotando suas vidas na previsibilidade imposta pela natureza ou pelas circunstâncias, todos se conformando como seres-para-a-morte, ${ }^{14}$ todos se constituindo "tipos", nunca sujeitos: mesmo os mais divertidos, mesmo os mais trágicos, mesmo os mais sábios, mesmo os mais belos. Todos, menos Vicente.

\subsection{O Homem em "Vicente"}

Um imortal: eis o que as piores situaçōes que possam ser-lhe infligidas demonstram o que o Homem é, na medida e que se singulariza na vaga multiforme e voraz da vida. Para pensar seja o que for a respeito do Homem é preciso partir dai.

Alain Badiou

14 Não surpreende, pois, que a maioria deles acabem mortos, e que a morte seja, em regra, o ponto de partida para a narração de suas vidas, em retrospectiva. 
Um imortal: eis o que é Vicente, na medida em que se singulariza na crista de um cerro a emergir das vagas, olhando a barca, sim, mas para encarar de frente a degradação que recusara. "Três vezes uma onda alta, num arranco de fim, lambeu as garras do corvo, mas três vezes recuou. A cada vaga, o coração frágil da Arca, dependente do coração resoluto de Vicente, estremeceu de terror. A morte temia a morte." ${ }^{15}$

Diferentemente da fábula bíblica, onde após quarenta dias de dilúvio Noé liberta uma pomba para que procure terra firme, na fábula escrita por Torga é um corvo quem toma a iniciativa do vôo, para surpresa e espanto dos habitantes da arca, bichos e homens igualmente definidos como o "resíduo da matéria palpitante reduzida a uma pura passividade vegetativa". Em meio aos seus pares, também o corvo se viu preso, num primeiro momento, ao instinto de conservação, até que lhe sobreveio um acontecimento, feito do cansaço daquela situação e da repulsa por sua submissão a ela.

E então ele parte. "A insólita partida do corvo foi presenciada por grandes e pequenos num respeito calado e contido. [...] O seu gesto foi naquele momento o símbolo da universal libertação". A partir daquele momento, Vicente não tinha mais nenhuma garantia, nenhuma segurança, nenhuma esperança. Avançava de peito aberto porque avançar era a única saída, avançava indiferente à sua sorte e ao seu destino, disposto a encarar o desconhecido e o devir, disposto a encarar a morte, tida como certa naquelas circunstâncias.

Vicente, porém, vivia. À medida que a barca se aproximava, foi-se clarificando na lonjura a sua presença esguia, recortada no horizonte, linha severa que limitava um corpo, e era ao mesmo tempo um perfil de vontade. [...] A significação da vida ligara-se indissoluvelmente ao acto de insubordinação. Porque ninguém mais dentro da Arca se sentia vivo. ${ }^{16}$

"s TORG $\Lambda, 1990$. p. 134.

"TORGA, 1990. p. 132. 
E, de repente, terra!... Não se sabe como nem de oncle teria surgido. Às vezes tem-se a impressão de que o próprio gesto de Vicente é que a forja sob as suas garras. E, na seqüência do conto, tem-se a certeza de que a terra não apenas nasce de sua vontade de pouso, como se mantém e se estende, afastando as águas, unicamente pela determinação do sujeito e por sua fidelidade absoluta ao gesto inicial, capaz de mudar o mundo.

Desde a partida da barca, que assinala a sua recusa da degradação partilhada pelas vítimas cla salvação divina, condenadas a serem testemunhas submissas da implacável tirania de Deus, Vicente torna-se o símbolo do Homem, como o entendem Badiou e Torga. Um "imortal". Por isso, diante do coração resoluto de Vicente, "a morte teme a morte". A morte como condenação, como ameaça, como terror e como destino último e inalterável - a morte como o Mal - teme a sua extinção diante daquele ser que se viu capturado e deslocado pelo processo de acontecimento de uma verdade. Este ser sabe que a sua eternidade não está vinculada à conservação de seu corpo, mas à consistência que o mantém parte pregnante desse sujeito de uma verdade que the aconteceu tornar-se.

Se há uma ética neste livro, certamente não é uma "ética dos direitos humanos", e não por acaso Torga terá optado por povoálo de bichos. Aí não se discutem direitos da vida contra a morte, nem direitos da sobrevivência contra a misćria. O que está em jogo são os direitos do imortal afirmando-se por si mesmos, ou os direitos do Infinito excrcendo sua soberania sobre a contingência do sofrimento e da morte. "Continuar!" - é a máxima de Badiou e de sua ética das verdades. "Continuar!" - é a máxima de Vicente, talvez um alter-ego do poeta, e de sua poética do sitjeito.

Diz Badiou:

Que no final morramos todos e que nào reste senào pó, isso não muda em nada a identidade do Homem como imortal no instante em que ele afirma o que está na contramào do querer-ser-umanimal a que a situaçio o expóe. Sabe-se que cada homem, imprevisivelmente, é capaz de ser esse imortal, em grandes ou pequenas circunstancias, por uma verdade importante ou 
secundária - pouco importa. A despeito de existir uma espécie biológica, um bípede sem penas cujo encanto não é evidente, em todo caso a subjetivaçào é imortal e constitui o Homem."

Sem dúvida alguma, "Vicente" é um dos contos mais marcantes de Torga. Seu protagonista prenuncia, em Bicbos, a figura do Menino, que em seus demais livros ergue-se como uma vontade contra os desafios do mundo e enfrenta o terror da conformação, configurandose, portanto, para Torga, como o seu mais forte leitmotiv.

A "alma" de Vicente sobrevive e se repete, assim, na alma de meninos que ora enfrentam as presas de um lobo, ora a ameaça de uma montanha amaldiçoada, ora a crueldade de um patrão, ora um terrivel assassino, ora a visão da agonia do pai, ora o retorno de um filho pródigo à terra, ora a esperança e a decepção em torno da expectativa de um presente. Nesses contos, Torga submete a criança a uma espécie de ritual de iniciação: não para a vida adulta, que representa em geral a passagem a uma condição de crescente resignação; mas para a vida autêntica, como esperança de sobrevivência da sensação de "imortalidade" que todo o ser humano experimenta espontaneamente na infância.

Por isso, é recorrendo à simbologia da criança que Torga recusa julgamentos prévios sobre qualquer manifestação de autenticidade do sujeito. Apesar disso, os estudiosos de sua obra insistem em ver nessa recusa de julgamento uma recusa do Bem. Eduardo Lourenço, por exemplo, insiste em ressaltar os momentos de sua obra nos quais o poeta invoca a Deus para se Lhe opor, ${ }^{18}$ esquecendo-se da razão que o move e que ele mesmo explica, em "Desfecho": "Não tenho mais palavras./Gastei-as a negar-te.../(Só a negar-te eu pude combater/O terror de te ver/Em toda a parte)".

José Augusto Mourão, por sua vez, afirma em seu ensaio "A Literatura e o Mal: Torga, Celan e Duras":

17 BADIOU, 1995. p.26.

${ }^{18}$ LOURENÇO, 1955. p.102. 
Orfeu Rebelde, Torga fará de toda a sua escrita uma confrontaçào direta dos deuses ou dos obstáculos que eles incarnam. Sobretudo em O Outro Litro de Job ou no Vicente. Mas o bumanismo soberano do nosso autor, a sua ética da subversào só dentro do paradigma religioso cristào se entendem. [...] O cono incarna a maldição, a pura insubmissão, o mal, a transgressâo. Deste combate quem sai vencido é o Criador. Ao Destinador do paraíso e da morte opòe-se o homem, causa de si e do partido do diabo. O paraíso na terra vive-se a partir da revolta hipostasiada num satanismo plenamente assumido."

Nessa interpretação, assim como na leitura de Nayade Anido: "Miguel Torga e a recusa do Divino", observa-se uma grande preocupação dos estudiosos com a perspectiva de Deus. Anido, em sua conclusão, enumera as possibilidades do Criador diante do desafio imposto pela Criatura, e angustia-se com o dilema vivido por Ele: "ou salva Vicente ou o deixa morrer. Mas cada uma dessas alternativas conduz indiscutivelmente a conseqüências terriveis". Tais seriam, para a autora, a aceitação da autonomia do humano por parte de Deus, numa ameaça à Sua onipotência; ou a imposição da Sua vontade sobre o humano, destruindo-o, o que resultaria numa ameaça à Sua própria existência, aniquilada quando já não houvesse quem $O$ cultuasse.

A flagrante tendência dos críticos de discutir a questão do ponto de vista do "divino" parece relegar a atitude do corvo a uma posição indigna de maior análise. Só porque Torga mencionou "Deus", jã Mourão viu no corvo uma “óbvia e natural” figuração do satanismo. O impulso para a identificação apriorística do Mal é evidente nessas análises, e revelador da atitude de um "humanismo soberano" que se atribuiria com muito mais propriedade aos críticos eles mesmos do que ao próprio Torga. Pois se observarmos a atitude de Vicente, veremos que ela tem menos de revolta, de rancor e de desafio do que de impulso, de instinto e de vontade. Veremos que cla tem muito do Menino: da inconsciente e bela ousadia de não-ser-ainda, que garante às crianças a certeza pura e simples de tudo-poder-ser.

19 MOURÃO, 1992. p.130. 
Vicente, portanto, não é o "Mal" porque enfrenta a "Deus". Vicente é um acontecimento, é o sujeito de uma verdade cujo ponto de partida é tão genuíno, tão autêntico, tão perfeito que não poderia ser senão um Bem. A emancipação é um Bem. A coragem é um Bem. A fidelidade a si mesmo é um Bem. Vicente não é Lúcifer, porque, ao contrário de Lúcifer, não aspira a um destino celestial. Lembremo-nos da advertência de Torga: "Sua sorte se ligara inteiramente ao telúrico destino". Mas, acima de tudo, Vicente não é uma vítima. O dilema nesta história quem o vive é Deus, e não o Homem. E nenhum dilema divino pode atingir o Homem que se imortaliza numa verdade, como o corvo que, calma e obstinadamente, "pousa na derradeira possibilidade de sobrevivência natural". Para ele não interessa se Deus hesita ou não diante de sua autonomia. E isso porque, ao que parece, diante de um imortal Deus nào tem qualquer alternativa.

\subsection{A impossibilidade do Bem como projeto, em A Ressurreiçāo}

Toda vontade coletiva de Bem faz o Mal.

Alain Badiou

O principal aspecto do humanismo que Badiou considera responsável pela visão do homem como uma vítima é a evidência consensual do $\mathrm{Mal}$, à qual se arraiga a ideologia ética contemporânea. O reconhecimento do "Mal", assim como toda a tentativa de reunir os homens em torno de uma idéia positiva do Bem, e mais ainda, de identificar o Homem por tal projeto, é na realidade, para ele, a própria fonte do mal:

Toda vontade coletiva de Bem faz o Mal. Esta sofistica é devastadora. Pois se trata-se apenas de priorizar, contra um Mal reconhecido $a$ priori, o compromisso ético, como se poderá considerar uma transformação qualquer do que é? De onde o homem retirará a força do ser imortal que é? Qual será o destino do pensamento, sobre o 
qual se sabe que ou é invenção afirmativa, ou nào é? Na realidade, o preço pago pela ética é o de um conservadorismo espesso. [...] Por sua determinaçào negativa e apriorística do Mal, a ética se nega a pensar a singularidade das situaçōes, princípio obrigatório de tocla açào propriamente humana. ${ }^{\text {n }}$

Miguel Torga discute uma idéia semelhante em seu conto "A Ressurreição", do livro Contos da Montanba, cuja conclusão de certa forma poderia ser transposta para a maioria das demais vinte e duas narrativas do livro, variações em torno do tema da ética e da justiça torguianas, baseadas na liberdade do sujeito e em sua fidelidade a si mesmo.

A história tem como ponto de partida uma situação de choque entre o representante do "Bem" instituído - Cristo Nosso Senhor, na pessoa do padre Unhão - e o que este considera o "Mal": a "endemoninhada gente" de Saudel, a quem descompõe em suas pregações: "Que ninguém presta. Que os pais são assim, que as mães são assado, que as filhas são porcas, que os filhos são brutos, que é tudo uma miséria". A pesar da posição de poder que o padre detém sobre a comunidade, o povo não consegue reconhecer como verdadeira aquela visão tão negativa de Saudel.

Saudel é deveras apresentada pelo narrador como uma terra "desgraçada e negra", com gente como "bichos vivendo em tocas". Mas a interpretação apriorística do padre sobre essa situação não coincide com a percepção do povo que ali vive, com a sua experiência: "Os homens cavam de manhà à noite, as mulheres parem quantas vezes a Virgem Maria quer, os rapazes e as raparigas vão com o gado... Quem iri meter coisas daquelas nos ouvidos de Deus?". Para o povo, Saudel nada tem de Mal nem de medonho. $O$ padre, porém, não pertence à comunidade; vem apenas aos domingos. Seu conhecimento de Saudel é generalístico, superficial, preconceituoso. Sua atitude é convencional: condenar, acusar, ameaçar, atribuir uma culpa ao povo e submetê-lo à encurralada condição de réu num processo previamente definido e sem respaldo na realidade. "Saudel, abismado, ouve.l...] Saudel desespera".

20 BADIOU, 1995. p. 28. 
À situação inicial segue-se a ação propriamente dita do conto, que consiste na realização das endoenças propostas pelo padre como "um acto coletivo de expiação". Para empregar a terminologia de Badiou, as endoenças nesse conto representariam uma manifestação movida por "uma vontade coletiva de Bem", que nasce da tentativa de identificar o indivíduo com uma visão prévia, programática, do Homem, doutrinando-o conforme os comportamentos, aspirações e caracteristicas tidos como ideais. No caso, o poder "educativo" da representação da "Paixão e Morte do Nosso Senhor Jesus Cristo" em Saudel teria a intenção de convencer o povo desconfiado da realidade de sua condição "maligna", de sua condição originariamente "pecadora". Em Saudel, no entanto, já ninguém estava "seguro da sua própria realidade".

Todo o conto lança mão desse artifício de confusào entre a realidade e a ficção para mostrar como verdades impostas jamais correspondem a uma verdade em si. A insegurança quanto à própria realidade não surge exatamente no momento da "transfiguração" das pessoas em personagens do drama, mas um pouco antes, no sentimento de descrédito do povo diante da imagem de Saudel que o padre tenta inutilmente impor. Por isso, não é com o espírito da "expiação" que Saudel aceita participar das endoenças. Não há sequer uma consciência clara a respeito dos limites, quem dirá dos objetivos da representação. Desde a escolha dos personagens, Saudel como que se tranforma em Jerusalém, e o homem chamado Coelho torna-se, aos olhos do povo, o próprio Cristo. É tal a identificação das pessoas com os papéis a elas atribuidos que a maioria já não consegue discernir o plano da realidade. Transportase para a representação, transformando-a, gradativamente, num evento concreto.

A conclusão prepara-se a partir da atitude de Perra, mulher do Coelho, que por razões pessoais, afetivas e até instintivas, preocupase com a fome real do marido, há horas na "cruz". Essa preocupação permite-lhe conservar o senso de realidade, ao contrário do resto do povo de Saudel, a essa altura mergulhado num frenesi hipnótico. Tornando-se o sujeito desta história, é ela quem deflagra a reação 
coletiva do povo, gritando "aqui-del-rei pelo seu homem", quando descobre ao fim da representação o seu desaparecimento, tal qual o Cristo, da "sepultura" onde fora colocado.

"Solidário com aquele desespero justificado, Saudel em peso caiu como um abutre em cima dos quatro facinoras e da tropa fandanga por conta de quem estavam a soldo". Inverte-se, então, a situação inicial. O choque não é mais entre o padre e a comunidade, mas entre elementos da própria comunidade, agora divididos. A reação espontânea das pessoas ao acontecimento é a luta, a briga, a guerra contra aqueles que eram, até há alguns dias, amigos e irmãos. A igreja transforma-se num "lago de sangue" e o padre Unhão perde toda a sua força e autoridade. Já não é, para a aldeia, o único interlocutor de um Cristo inacessivel; Cristo se familiarizara definitivamente em sua descida à terra e a Saudel no corpo de um de seus membros. Saudel já não precisa do padre para saber como se conduzir.

A tentativa de impor uma "vontade coletiva de Bem" através da santa cerimônia tem então um desfecho selvagem, terrivel, violento, em tudo avesso à realidade pacata daquele lugar e daquele povo. O "campo de guerra" em que se transforma a igreja também transforma a vida em Saudel num palco de ódios recém-deflagrados, de disputa e de terror, bem mais próximo de um retrato concreto do Mal do que a abstração fantasiosa a que o padre recorria para definir o lugar.

O resultado do "ato coletivo de expiação" é desastroso:

surdos às razỏes do abade, só atentos à voz íntima da indignaçào, todos vingavam como podiam a injustiça cometida, numa viril ressurreição do sagrado bumano, que apenas o sino, a repicar lá fora, parecia compreender e festejar.

Vê-se, por essa observação final, que o título "A Ressurreição" não se refere, como se poderia supor pelo tema, àquela do Cristo, mas à ressurreição do que Torga chama de o "sagrado humano", que nada tem a ver com uma definição apriorística, como a religiosa, do Bem. O "sagrado humano" transborda do gesto autônomo da comunidade motivada por um sujeito e da adequação final de seus 
atos aos seus pensamentos. Saudel ressurge de sua condição submissa pelo ato de insubordinação, por sua coragem de assumi-lo, e por isso é "festejado". Infelizmente, porém, é de dentro de um Mal desnecessário que ocorre essa última e real transfiguração de Saudel escravizada em Saudel liberta.

Poderíamos dizer que, nas palavras de Badiou, o Mal adviria, nesta situação proposta por Torga, da fidelidade do povo a um simulacro, diferentemente da fidelidade a um acontecimento. "Quando, com nomes extraidos dos processos reais de verdade, uma ruptura radical numa situação convoca, em lugar do vazio, a particularidade "plena" ou a substância suposta dessa situação, podemos dizer que se tem um simulacro de verdade" ${ }^{21}$

Se a vida de Cristo a seu tempo foi da ordem de um acontecimento, a experiência das endoenças num lugar como Saudel foi da ordem do simulacro, pelo menos até o momento em que o povo expressou a sua vontade, criando um acontecimento novo e diferente, que redimensiona toda a representação. Um acontecimento legítimo, porque restitui os sujeitos às suas personalidades, e porque convoca um vazio - $\mathbf{a}$ indefinição sobre as conseqüências do ato em questão - em lugar da plenitude dogmática do efeito aspirado pelo padre Unhão ao sugerir o drama.

Para Badiou, o Mal às vezes nasce, como neste caso, de uma vontade coletiva de Bem, ou da tentativa de normatizar e generalizar o Bem em torno de um simulacro.

Simulacro deve ser tomado em seu sentido forte: todos os traços formais de uma verdade estão em funcionamento no simulacro. Não apenas uma nominaçâo universal do acontecimento, induzindo a força de uma ruptura radical, mas também a obrigação de uma fidelidade e a promoçào de um simulacro de sujeito, erigido - sem que nenhum imortal, entretanto, advenha - por cima da animalidade humana dos outros, daqueles que são arbitrariamente considerados não pertencentes à substância comunitária cuja promoçào e cujo domínio são promovidos pelo simulacro do acontecimento. ${ }^{22}$

21 BADIOU, 1995. p. 83.

22 BADIOU, 1995. p. 83. 
No caso das endoenças, a "substância comunitária" que o padre Unhão procurava promover, através de um simulacro do acontecimento que foi a Paixão de Cristo, era, obviamente, a razão da Igreja. "A fidelidade ao simulacro tem por conteúdo a guerra e - massacre" - diz Badiou, e isso é exatamente o que ocorre na história de Torga. A ressurreiçâo de que ele fala e a qual celebra, portanto, certamente não se vincula às conseqüências negativas da guerra que se instaurou em Saudel, mas ao fato de o "sagrado humano" - o imprevisível "imortal" - ter triunfado em meio à celebração hipnótica e ritualística que tinha como propósito oculto convencer a comunidade de sua condição pecadora e maligna, uma condição contra a qual a natureza rude e simples daquele povo sofrido, interiormente, se rebelava.

\subsection{A razão de Caim em "O Alma-Grande"}

O núcleo de dominio interno da ética ế ter sempre que decidir quem morre e quem nảo morre.

Alain Badiou

Condenar... A desgraça é que precisamente quando a sentença vem, a mazo parece estar sempre do lado do criminoso. Indefeso, todo o ser tem razão.

Miguel Torga

Em seu trabalho, Badiou vê a ética humanista como o instrumento de domínio ocidental da morte. Quer seja determinada como representação consensual do Mal ou como preocupação com o outro, a ética designa antes de tudo a incapacidade, característica do mundo contemporâneo, de nomear e querer um Bem. "O reino da ética é sintoma de um universo dominado por uma singular combinação de resignação diante do necessário e vontade puramente negativa, e mesmo destrutiva. Essa combinação, é preciso designá-la como niilismo. Nietzsche mostrou muito bem que a humanidade prefere querer o nada do que nada querer". ${ }^{23}$

23 BADIOU, 1995. p. 43. 
Para o autor, isto esclarece o privilégio que a ética dá, entre as "questões de sociedade" que povoam o nosso cotidiano, ao sempiterno debate sobre a eutanásia.

A palavra eutlanásia coloca claramente a questão: Quando e como, em nome de nossa idéia de felicidade, pode-se matar alguém? Ela nomeia o núcleo estável a partir do qual opera o sentimento ético. Conhecemos o uso constante que o "pensamento" ético faz da "dignidade humana". Mas a combinação entre o ser-para-a-morte e a dignidade constrói precisamente a idéia da "morte digna". Comissōes, imprensa, magistrados, políticos, padres e médicos discutem uma definição ética, sancionada pela lei, da morte dignamente administrada. ${ }^{34}$

Para o pensamento ético, o sofrimento e a decadência não são "dignos", não se adequam à imagem polida, jovem, bem-nutrida que se faz do Homem e de seus direitos. "Quem não vê" - indaga-se Badiou - "que o debate sobre a eutanásia designa sobretudo a falha radical de simbolização em que habitam hoje a doença, a velhice $e$ a morte, o caráter insuportável de sua visão para os vivos? A ética está aqui na junção de duas pulsões que não são contraditórias senão aparentemente: definindo o Homem pelo não-Mal, portanto pela "felicidade", pela saúde e pela vida, ela está ao mesmo tempo fascinada pela morte e é incapaz de inscrevê-la no pensamento". ${ }^{25}$

Para Badiou:

O saldo desse balanço é a transformação da própria morte em um espetáculo tào discreto quanto possivel, em um desaparecimento do qual os vivos têm o direito de esperar que não anule seus hábitos, irreais, de satisfaçào sem conceito. O discurso ético é portanto ao mesmo tempo fatalista e resolutamente nào-trágico: ele abre passagem para a morte sem opor-lbe o imortal de uma resistência. ${ }^{26}$

É curioso como Miguel Torga vai ao encontro desse ponto de vista, sobretudo nas narrativas de seu livro Novos Contos da Montanba, nas quais a morte ou a condenação de um indivíduo, forjada ou aceita pelo grupo e justificada como vontade coletiva de

24 BADIOU, 1995. p. 48.

25 BADIOU, 1995. p. 48.

${ }^{26}$ BADIOU, 1995. p. 48. 
"bem" é severamente contestada ( $O$ Alma-Grande, O Leproso, A Confissão, O Senbor), ${ }^{27}$ ainda quando o ato de matar, no contexto do livro, surpreendentemente não figura como condenável a priori.

Em O Caçador, por exemplo, o protagonista afirma: "Matara, sim, e matava ainda, se podia, mas não era com ódio, a gritar maldição, que o tiro partia. [...] Porque uma coisa sabia cle: é que quase um século de caça não lhe endurecera nem the empeçonhara a alma". ${ }^{28}$ Da mesma maneira, a morte - envolvida no duelo silencioso entre os personagens de A Caçada; ou nos gestos extremos e individuais de frios assassinos, como o Lomba, de Repouso; ou ainda no sacrifício isolado e "piedoso" de uma rês pelo Pedro, num momento imprevisto, até epifânico, deste estranho conto que é Milagre ${ }^{2)}$ - pode ser predadora, instintiva, vingativa,

${ }^{27}$ Em OAlma-Grande vemos a vítima se insurgindo contra o consenso comunitário da prática da cutanásia; $\mathrm{em}$ O Lepraso vemos o enfoque trigico do indivíduo doente que se insurge até suas últimas forças contra o consenso sobre a sua exclusào, que culmina com o seu extermínio num linchamento coletivo; em A Confissão acompanhamos a resistência de um inocente e sua luta pela verdade apesar da tortura e do julgamento social aos quais é submetido; c em O Senbor, surpreendemos o ser humano sobrepujar seu papel social, na figura de um padre que interrompe a ladainha coletiva da morte e toma $\mathrm{cm}$ suas mãos solitárias a tarefa concreta de salvar as vidas desenganadas que viera encomendar a Deus.

2s TORGA, 1986. p. 58.

"A questào da "morte digna" é abordada em dois contos neste livro: Milagre e OAlma-Grande. Enquanto o primeiro expressa uma aceitaçào da justificativa habitual que vê na abreviaçào do sofrimento uma razio piedosa e humana para matar (ou morrer), o segundo expressa uma revolta contra essa idéia e uma crítica contra essa açào. A contradiçào, contudo, é apenas aparente. Mais uma vez, o que parece estar em jogo nào sào os atos em si, mas a sua veracidade. Quando o Pedro sacrifica a rês ferida, está em completo isolamento e ainda sob a emoção do gesto inesperado da mulher doente, que acaba de se suicidar. Há uma forte motivaçào pessoal para a sua decisào, que é oposta à mecanizaçào e à ritualizaçào do gesto "piedoso" do abafador, cm O AlmaGrande. Nảo há contradiçào nas duas abordagens, porque as razóes dos personagens são diferentes. Para o Pedro o sacrifício é a consequêencia casual de uma experiência única e irrepetivel, enquanto para o abafador, o sacrificio de outros é apenas uma profissão. 
gratuita e imprevisivel, mas jamais se configura como uma forma de execução consensual e programática.

Nos contos de Torga, portanto, a distinção é clara: o horror não advém da morte em si, nem mesmo do ato isolado de matar, mas da morte transformada pela ética em instrumento de controle social da vida em grupo, a morte institucionalizada, administrada pela medicina, pela religião ou pela justiça visando ao "bemcomum". O horror advém quando, em nome de um conceito de "vida digna", assume-se implacavelmente a necessidade de pôr fim às vidas condenáveis ou "indignas", ou mesmo à situação de viver "indignamente". Consideraremos aqui brevemente a forma como a questão da eutanásia, de fundamental importância para esta discussão, é abordada no conto O Alma Grande.

Talvez nenhuma situação vitime tanto uma criatura quanto a doença. Ela subjuga o corpo e mina a energia como o mais covarde dos algozes, como o pior dos inimigos, porque, como diz Torga, divide o sujeito em duas metades: uma "apostada em perdê-lo" e a outra em defendê-lo. A luta se trava no interior do próprio corpo, entre o ser e ele-mesmo, entre a esperança e o desespero, entre a vontade e o cansaço.

Mas nenhum corpo doente é letárgico: ao contrário. É forçosamente um corpo ativo, em intensa e instintiva reação ao desafio imposto pelo mal que o acomete, não importa o quanto o espetáculo dessa luta pareça desagradável e insuportável aos que a testemunham. A função do "abafador" parece prestar mais um serviço à comunidade para quem o doente constitui um mal e um transtorno do que ao próprio doente, mesmo aquele que, desenganado pela ciência e entregue à depressão, manifesta o desejo de morrer.

Em seu conto, Torga dá aos protagonistas nomes de vítimas famosas na Bỉblia. O pai, na história, é Isaac, personagem bíblico vítima de seu pai Abraão, que por ordem divina teria sacrificado o único filho temporão para provar sua amizade a Deus, se não fosse interrompido a tempo. O menino, na história, é Abel, personagem bíblico vítima da vingança de seu irmão Caim, preterido no amor 
de Deus. O algoz, na história, não tem nome. É conhecido sob uma alcunha de tom piedoso: o Alma-Grande, o administrador da morte, o senhor último dos destinos, agente de "Deus" ou da Lei que obriga os homens ao cumprimento de "papéis" predeterminados.

O Alma-Grande, no conto, não é simplesmente - ou não é absolutamente - um individuo. É o agente de uma vontade coletiva, de um consenso em torno da aceitação do sacrifício de criaturas tornadas indefesas pelo sofrimento. Como qualquer carrasco, serve de instrumento à execução de uma lei, sem questioná-la. "Verbaliza" o código social e o legitima em um gesto. De uma certa maneira, resume o discurso ético: abre passagem para a morte sem opor-lhe o imortal de uma resistência.

Sob este aspecto, a história de Torga é profundamente antiética: é a história de uma resistência individual e solitária à força cega e à crueldade insana de um código coletivo de Bem. Isaac não se conforma em apenas lutar pela própria vida. Ele precisa destruir o que o Alma-Grande representa: a imagem da cegueira comum e conformada de seres-para-a-morte, unidos e resignados num mesmo entorpecimento da Vontade diante do Desconhecido. Não é à-toa que há tantos olhos neste conto, tantas referências à visâo. É como se Isaac contestasse o seu destino bíblico de vítima, e se voltasse contra Abraão - não enquanto pessoa, mas enquanto símbolo de subserviência cega a um código totalitário de amor e servidão.

Assim, o Isaac de Torga sacrifica o "Abraão" que havia no Alma-Grande, abrindo os olhos do carrasco, enfim, para o infame de sua condição de assassino, até então não percebida por ele, no desempenho honesto de sua função "humanitária". E o faz sob os olhos de seu filho Abel, que durante todo o relato "precisa compreender" alguma coisa.

A clúvida de Abel é o aspecto mais intrigante deste conto. Os seus olhos testemunham dois atos idênticos, porém inverticlos. No primeiro, a sua presença é ativa: interfere na cena e faz do gesto habitual e mecânico do abafador um acontecimento, com todo o poder de revelação de uma verdade. Essa verdade tanto atinge o Alma-Grande - restituindo-lhe a consciência e o medo, elementos 
de uma humanidade perdida ao longo dos anos de exercício do "humanitarismo" -, como também atinge Isaac, dando-lhe uma razão para viver mais forte do que a mera sobrevivência. Ele viveria para expurgar $o$ abafador e contestar, num gesto individual de vingança, a legitimidade de sua função.

A presença de Abel no segundo momento, por isso, é passiva. Isaac não pretende inspirar uma revolta nem animar outros ânimos em torno de uma nova concepção do Bem. O acerto de contas é entre duas consciências em absoluta igualdade de condições. Dois seres tornados resistentes. Dois Imortais, como diria Badiou. Envolver no drama a "opinião pública" seria perigoso. A opinião pública é um bloco surdo e cego, que passa, como diz Torga, "da agonia à morte e da morte à ressurreição, na inconsciência de quem passa do calor ao frio e do frio novamente ao calor".

A esse respeito, vale a pena registrar as idéias de Badiou sobre a "opinião pública". Toda verdade, segundo Badiou, depõe os saberes constituídos e assim se contrapõe às opiniões: "Pois são denominadas opiniôes as representações sem verdade, os escombros anárquicos do saber circulante". As opiniões são o cimento da sociabilidade, a matéria-prima de toda comunicação, mas o que elas comunicam "não tem um grama de verdade". Nem, aliás, de falsidade, como afirma o autor: "A opinião está aquém do verdadeiro e do falso, justamente porque sua única função é ser comunicável".$^{30}$ Para o autor:

Aquilo que surge de um processo de verdade, em contrapartida, não se comunica. A comunicação é apropriada apenas às opiniōes. Para tudo o que concerne às verdades é preciso que tenha havido encontro. [...] A ética de uma verdade é totalmente o contrário de uma "ética da comunicação". É uma ética do real, se continua sendo verdade que todo acesso ao real é da ordem do encontro. A ética de uma verdade se opõe absolutamente à opinião - e à ética, simplesmente, que não passa de um esquema de opinião."

\footnotetext{
${ }^{30}$ BADIOU, 1995. p.63.

31 BADIOU, 1995. p.63.
} 
A ética das verdades exige, portanto, tamanha distância das opiniōes que se torna praticamente a-social. Por isso, o exemplo de Torga nesse conto, como em tantos outros, é da ordem de uma ética das verdades. A verdade pulsa no isolamento das consciências, no silêncio de gestos autênticos, que passam quase sempre despercebidos pela maioria, embora nem sempre se esgotem na individualidade egocêntica de seus atores. Há a possibilidade de um acaso, de uma testemunha imprevista a quem a verdade também possa atingir, sem a coação de um credo. É assim que a verdade do drama de Riba Dal atinge o menino Abel, que ao ver o pai sufocando o Alma-Grande "com o garrote das mãos e a força do joclho" compreende finalmente o que o Alma-Grande fora fazer à sua casa, durante a agonia do pai.

"Não matarás" - suplica o algoz tornado agora vítima, erguendo em sua defesa o texto de uma lei que ele mesmo contribuíra tantas vezes para denegar. Uma lei sem força de verdade, uma lei sem a autoridade do encontro, uma lei da ordem da opinião, da ordem da palavra. "Assim era no Evangelho. Fora dele, numa lei diferente, a moral tinha outros caminhos, como o próprio AlmaGrande sabia". Assistindo ao desenlace impiedoso do drama, o Abel de Torga compreende, talvez, o que o Abel da Bíblia não teve a oportunidade de compreender. A razão do gesto de Caim: "consciência em processo activo contra o arbítrio que diviclia os seres em eleitos e condenados", como diz Torga, em Vicente. Afinal, por que uns deveriam ser preferidos e outros preteridos?

A ética das verdades tem algo da razão de Laim. É a consciência do animal humano tornado stujeito rebelando-se contra a idéia de uma lei absoluta, de uma ética teoricamente fundada na idéia de um Homem universal que, na prática, se apresenta sempre cindido. Quem não percebe que, ao debruçar-se sobre a miséria do mundo, a ética dos direitos humanos esconde por trás de seu Homem-vítima, o Homem-bom, o eleito, que fará a intervenção salvadora?... Por trás de cada "pobre" Isaac não se oculta um "bondoso" Alma-Grande, com a sua intervenção assassina previamente absolvida pela comunidade?... 
Designando o Mal a priori, a ética cria uma justificativa viável para a condenação do homem à morte, seja em função da manutenção da ordem social (a pena de morte), seja em nome da "consideração" pelo sofrimento do outro (a eutanásia). À imagem e semelhança de Deus, a lei humana - jurídica, médica ou religiosa - arvora-se do direito de selecionar eleitos e condenados e de manipular a vida à margem da verdade enquanto experiência individual e única, transformando-a num conceito sujeito à massificação e à "opinião pública". No pequeno universo de seus personagens despretensiosos, Torga traz à baila essa questão, mostrando que o Mal advém quando uma Verdade ou um desejo de Bem pendem para um conservadorismo "niilista". Pois, como diz Badiou, "cada época - e nenhuma vale mais que alguma outra - tem seu próprio aspecto niilista. Os nomes mudam, mas reencontramos sempre sob esses nomes a articulação de uma propaganda conservadora com um obscuro desejo de catástrofe". É contra esse conservadorismo que se insurge o poeta do Livro de Horas, que em sua "confissão de ser Homem" expressa não uma apologia do Humanismo, mas o corolário de uma ética do encontro, da experiência e das verdades, quando diz:

Aqui, diante de mim, eu, pecador, me confesso

de ser assim como sou.

Me confesso o bom e o mau

que vão ao leme da nau

nesta deriva em que vou. [...]

Me confesso de ser tudo

que possa nascer em mim.

De ter raizes no chăo

Desta minha condição.

Me confesso de Abel e de Caim. 


\section{Referências Bibliográficas}

ANIDO, Nayade. Miguel Torga e a recusa do Divino. Colóquio/Letras 24, p. 31-40, 1975.

AREAS, Vilma; SILVEIRA, Jorge Fernandes da. Análise de Novos contos da montanba. Cadernos da PUC, Rio de Janeiro, n. 9, p. 51-62, maio 1972.

BADIOU, Alain. Ética - um ensaio sobre a consciência do mal. Rio de Janeiro: Relume-Dumará, 1995.

BADIOU, Alain. Para uma nova teoria do sujeito. Rio de Janeiro: RelumeDumará, 1994.

BATAILLE, Georges. A literatura e o mal. Porto Alegre: L\&PM, 1986.

GEREMEK, Bronislaw. Os filbos de Caim - Vagabundos e miseráveis na literatura européia. São Paulo: Companhia das Letras, 1995.

LOPES, Teresa Rita. Além, aqui e aquém em Miguel Torga: análise de Vicente. Colóquio/Letras 25, p. 34-49, maio 1974.

LOURENÇO, Eduardo. O desespero humanista de Miguel Torga e o das novas gerações. Tempo e Poesia. Porto: Editorial Inova, 1974. p. 85-123.

NIETZSCHE, Friedrich. Gaia ciência. São Paulo: Hemus, 1982.

NOVAES, Adauto (Org.). Etica. São Paulo: Companhia das Letras, 1992.

MOURÃO, José Augusto. A literatura e o mal: Torga, Celan e Duras. Colóquiad Letras 125/126, julho/dezembro 1972, p. 129-138.

RODRIGUES, J. N. Cunha. Representaçōes da Justiça em Miguel Torga. Jornal de Letras, Artes e Jdéias. Lisboa, Ano XIV, n. 634, 1-14/2/1995.

TORGA, Miguel. Bichos. 18ª ed. Coimbra: Gráfica de Coimbra, 1990.

TORGA, Miguel. Contos da montanha. 6. ed. Coimbra: Gráfica de Coimbra, 1982.

TORGA, Miguel. Novos Contos da Monlanba. 13. ed. Coimbra: Gráfica de Coimbra, 1986.

TORGA, Miguel. O Outro Lium de Jó. Coimbra: Gráfica de Coimbra, 1986.

TORGA, Miguel. Diário IV. Coimbra, Gráfica de Coimbra, 1986.

TORGA, Miguel. Diârio V. Coimbra, Gráfica de Coimbra, 1994. 


\section{Resumo}

Estudo que procura analisar a fiç̧ão de Miguel Torga através dos conceitos de Alain Badiou, mostrando-o como defensor de uma "ética das verdades" mais do que de uma "ética dos principios", ressaltando a autonomia de suas idéias e a diferença de sua posiçăo no contexto humanista do Neorealismo português.

\section{Abstract}

This essay tries to analyse the fiction of Miguel Torga through Alain Badiou's concepts, showing him as a defensor of an "ethics of the truths" more than of an "ethics of the principles", evidencing the authonomy of his ideas and the difference of his position in the humanist context of Neo-realism in Portugal. 